Saeculum Christianum

t. XXVII $\cdot 2 / 2020$

s. $89-102$

\title{
SLAWOMIR KOŚCIELAK
}

The Institute of History, University of Gdansk

ORCID: 0000-0001-5176-0622

\section{ANGLICANS, PRESBYTERIANS AND OTHER BRITISH RELIGIOUS GROUPS IN GDANSK IN THE $17^{\mathrm{TH}}-18^{\mathrm{TH}}$ CENTURIES}

\begin{abstract}
This article presents the religious aspects of the community of emigrants from the British Isles, mainly Scots, in Gdańsk. They tried to provide for their religious needs already in the Middle Ages, as evidenced by the existence of chapels and altars in some of the churches in Gdansk. After the success of the Reformation, mainly Scottish Presbyterians settled in Gdansk. Clergymen from their home country were brought in for their ministry. Both the Presbyterian clergy and the wealthy Scottish merchant elite of this denomination ruled the sacred building acquired in 1707, called the English Church. However, only few of the Presbyterians living in Gdansk identified with this building - according to legal arrangements, having the character of an "ethnic" temple - together with the Anglicans. Most Scots - by entering into family relationships - slowly melted into the community of the city on the Motława, using other Calvinist facilities. In addition to Presbyterians and very few Anglicans and Catholics there, English radicals, Chialists and Quakers, also tried to settle in Gdansk, but the city's unfavourable legislation and deterrent actions effectively prevented this transfer.
\end{abstract}

Keywords: coexistence between religions, ethnic minorities, Calvinism

\section{Streszczenie}

Niniejszy artykuł przedstawia religijne aspekty funkcjonowania w Gdańsku społeczności emigrantów z Wysp Brytyjskich, przede wszystkim Szkotów. O zaopatrzenie swoich potrzeb religijnych zabiegali oni już w średniowieczu, o czym świadczy istnienie kaplic i ołtarzy w niektórych z gdańskich kościołów. Po sukcesie reformacji osiedlali się w Gdańsku przede wszystkim szkoccy prezbiterianie. Do ich posługi sprowadzono duchownych z kraju macierzystego. Zarówno prezbiteriańscy duchowni jak i zamożna szkocka elita kupiecka tego wyznania zdominowała pozyskany w 1707 r. obiekt sakralny, tzw. Kościół Angielski. Tylko część zamieszkałych w Gdańsku prezbiterian identyfikowała się jednakże z tym obiektem zgodnie z prawnymi ustaleniami, mającym charakter świątyni „etnicznej” - symultanicznej z anglikanami. Większość Szkotów - zawierając związki familijne - wtapiała się powoli 
w społeczność miasta nad Motławą, korzystając z innych obiektów kalwińskich. Obok prezbiterian oraz śladowo występujących tu anglikanów i katolików próbowali osiedlić się w Gdańsku również angielscy radykałowie, chiliaści i kwakrzy, ale nieprzychylne im ustawodawstwo miejskie oraz akcje prewencyjne skutecznie uniemożliwiły ten transfer.

Keywords: coexistence between religions, ethnic minorities, Calvinism

\section{Preliminary Notes}

A s one of the biggest production and exchange centres in the Baltic Sea Basin, Gdansk has been the focus of attention of merchants and entrepreneurs from Western Europe since the Middle Ages. The city's membership in the Hanseatic League played an important part in attracting this attention. After the Thirteen Years' War (1454-66), when Gdansk was granted a wide range of self-governing and trade privileges as part of the Kingdom of Poland, and later the Polish-Lithuanian Commonwealth, interest in the city became much greater. Business connections between Gdansk and the British Isles had also been developing since the Middle Ages. As a result, many British people - English, but most of all Scottish - settled down in the city on the Motława River and its neighbourhood. In modern times they were not only Catholics but also Anglicans, Puritans, and most often, Scottish Presbyterians. Radical Chiliasts and Quakers also occasionally sought refuge there. It is, therefore, worth summarising our knowledge of the life of all these denominational groups in Gdansk in the $17^{\text {th }}$ and $18^{\text {th }}$ centuries.

In previous researches, considerable attention has been paid to the business contacts and relations between Gdansk and the British Isles. This issue was the topic of one of the first British monographs on the inhabitants of Scotland settling in both parts of Prussia (East and West), ${ }^{1}$ although the author of the monograph did not fail to outline the religious motives behind this settlement too. Also, some Polish researchers (including Maria Bogucka, ${ }^{2}$ Zenon Guldon and Lech Stępkowski ${ }^{3}$ ) have studied the economic issues in relation to British countries. The issue of the merchant community of British origin in Gdansk in the $18^{\text {th }}$ century and the transfer of English culture to the area has also been recently discussed in an in-depth monograph written in German by Almut Hillebrand. ${ }^{4}$ Martha Dunsby, who was connected with the Anglican community in the Free City of Gdansk during the interwar period, wrote about the English religious community in Gdansk, and she did so in the very

\footnotetext{
1 T.A. Fischer, The Scots in Eastern and Western Prussia, Edinburgh 1903. An important supplement to this volume is the following collection of documents on contacts between the Scots and Poland in the modern era, which was published more or less at the same time: Papers Relating to the Scots in Poland 1576-1793, ed. A.F. Steuart, Edinburgh 1915.

2 M. Bogucka, Obcy kupcy osiedli w Gdańsku w pierwszej połowie XVII w. „Zapiski Historyczne”, 37/1972, vol. 2, pp. 59-82; eadem, Scots in Gdańsk, in: Ships, Guns, Bibles in the North Sea and Baltic States, C. 1350C.1700, eds. A.I. Macinnes, T. Riis, F. Pedersen, East Lothian 2000, pp. 39-46.

3 Z. Guldon, Żydzi i Szkoci w Polsce w XVI-XVIII wieku. Studia i materiały, Kielce 1990; Z. Guldon, L. Stępkowski, Ludność szkocka i angielska w Polsce w połowie XVII w., "Kwartalnik Historii Kultury Materialnej”, 2/1982, pp. 201-214.

4 A. Hillebrand, Danzig und die Kaufmannschaft grossbritannischer Nation. Rahmenbedingungen, Formen und Medien eines englischen Kulturtransfers im Ostseeraum des 18. Jahrhunderts, Frankfurt am Main 2009.
} 
accessible form of a popular science article. ${ }^{5}$ Regrettably, having access to the archives of the so-called "English Church," she took advantage of these records to a very limited and superficial degree. Unfortunately, due to the Second World War, these documents did not survive and therefore, the question of religious preferences of the inhabitants of Gdansk in the $17^{\text {th }}-18^{\text {th }}$ century can only be investigated indirectly, by using parish registers of other Gdansk religious organisations as well as the snippets of information contained in other documents, dating back to those times, together with older literature on the subject. In an attempt to reconstruct the presence of British denominational groups in Gdansk in the modern era, it is also worth referring to the recent literature treating these issues in a broader context, with reference to the entire Polish-Lithuanian state. In particular, works by Anna Biegańska ${ }^{6}$ and a monograph by Peter Paul Bajer ${ }^{7}$ are worth pointing out in this category. The intermingling of the Calvinist community connected with the main centres of this denomination and the group of Scottish Presbyterians gathered around the so-called English Church, which was nominally founded at the beginning of the $18^{\text {th }}$ century for the Anglicans, will remain a unique phenomenon on the city's scale. The presentation of this phenomenon is another purpose of this article.

\section{The religion of the newcomers from the British Isles during The Reformation}

The first newcomers from the British Isles who, since the $14^{\text {th }}$ century, had been settling in Gdansk and its neighbourhood (such as the Scots in church estates near Gdansk which for that reason bore the names of Stare Szkoty (Old Scotland) and Nowe Szkoty (New Scotland)) were certainly orthodox Catholics. Around the year 1475, the Scots living inside the city walls had at their disposal a separate altar, called the Scottish altar, in the Dominican church of St. Nicholas in the Main Town. They would also attend services in the monastic church of St. Bridget in the Old Town. ${ }^{8}$

With the onset of the Reformation, the situation became much more complex. Firstly, Henry VIII, the king of England, with the pronunciation of the Act of Supremacy and the creation of the Church of England (1534), stood in favour of the Protestant wing. Secondly, after 1550, the radical Protestant movements conquered the Kingdom of Scotland. Gdansk, having obtained the denomination privilege (1557), would often use foreign mercenaries, including those from the British Isles, to defend its economic rights and freedoms. In 1577, seven hundred Scottish soldiers representing Calvinist Presbyterianism and led by William Stuart, were hired by the citizens of Gdansk to defend the city against the Polish king, Stephen Báthory. ${ }^{9}$ Two Catholic churches (Catholics being considered the supporters of the king) were taken away by the Gdansk authorities and put at the disposal of these soldiers.

\footnotetext{
5 M. Dunsby, Die Englische Kirche in Danzig, „Mitteilungen des Westpreussischen Geschichtsvereins“, 31/1932, No. 1, pp. 1-12.

6 A. Biegańska, Wielka emigracja Szkotów w Polsce, druga połowa XVI - koniec XVIII w., a Ph.D. thesis, Uniwersytet Sląski, Katowice 1974; eadem, In Search of Tolerance: Scottish Catholics and Presbyterians in Poland, "Scottish Slavonic Review", 1991, No. 17.

7 P.P. Bajer, Scots in the Polish-Lithuanian Commonwealth, $16^{\text {th }}-18^{\text {th }}$ Centuries: The Formation and Disappearence of an Ethnic Group, Leiden-Boston 2012. See also Britain and Poland-Lithuania. Contact and Comparison from the Middle Ages to 1795, eds. R. Unger, Jakub Basista, Leiden-Boston 2008.

8 M. Dunsby, op. cit., p. 1.

$9 \quad$ Ibidem, p. 1-2. See also: P.P. Bajer, op. cit., p. 149.
} 
These were the monastic churches of the Dominican brothers - St. Nicholas' church and the church of St. Bridget belonging to the Order of the Most Holy Saviour (Brigittines). Scottish Calvinists removed some elements of Catholic furnishings from these churches. ${ }^{10}$ In both these churches, the spiritual needs of the soldiers were taken care of by a Presbyterian clergyman, Patrick Grieg, who was brought from Scotland. ${ }^{11}$ The war ended in December 1577 with a compromise agreement between the conflicting parties and the monastic churches were returned to their previous owners. The trace of the Scottish soldiers' presence in Gdansk during these times are the tombs and epitaphs. One of the epitaphs is mentioned with reference to St. Mary's, the main Lutheran church in the city. The epitaph is dedicated to a Scottish officer, Presbyterian, Robert Gurlay, who fell defending the city in $1577 .{ }^{12}$

The second (Calvinist) Reformation started in Gdansk in the mid-80's of the $16^{\text {th }}$ century and many preachers and ministers reporting to the Gdansk Spiritual Ministerium were in favour of the movement. At the turn of the $16^{\text {th }}$ and $17^{\text {th }}$ century, Calvinism won the support of the majority of the city elites, patricians, officials and those practising liberal professions. The masses and some of the influential patrician families, however, remained Lutheran. The edict of 1612 of King Sigismund III ordering that the members of the Council and of the Bench be elected only from among Catholics (which was impossible, anyway) and Lutherans constituted the advantage of the latter denomination but did not eliminate the influence of Calvinism entirely. At the peak of their influence, Calvinists had their clergymen in nearly all parish and hospital churches in Gdansk, but eventually the clergymen remained in only two centres - St. Peter and Paul's church in the Old Suburb (Stare Przedmieście) and at St. Elisabeth's church in the Old Town. ${ }^{13}$ Many patricians were still included in the group of the followers of John Calvin's teachings and eagerly supported the people of their own denomination being accepted into the ranks of Gdansk merchants. Such distribution of power made Gdansk a multi-denominational city, especially because the Catholics retained their influence, although it was initially marginal. Anglicans coming to Gdansk from the British Isles on business and, to a greater extent, the Scottish Presbyterians, whose countrymen were already there, would feel at ease in such a well-balanced religious environment.

However, with its prevailing Protestant character, Gdansk hardly ever attracted Catholics emigrating from England and Scotland. The documented presence of English Catholics there, most often charged with special tasks, was rare. Jacob Bosgrave, a Jesuit of English origin, an outstanding mathematician and, for that reason, a professor at many colleges of the Jesuit order, lived in Gdansk for some time in 1578. He was accompanying another Jesuit, Antonio Possevino, a special papal envoy to Sweden on a secret mission. However, since

\footnotetext{
10 According to Fischer, they were also provided with services by a preacher from St. Elisabeth's church, who carried out pastoral work for them (and for the Dutch) in the Calvinist way. T.A. Fischer, op. cit., p. 128. See also: S. Kościelak, Katolicy w protestanckim Gdańsku od drugiej połowy XVI do końca XVIII wieku, Gdańsk 2012, p. 66.

11 T.A. Fischer, op. cit., p. 126.

12 Ibidem, p. 127. M. Dunsby, op. cit., p. 2. See also: G. Frisch, Der Sankt Marien Pfarrkirchen in Dantzig inwendige Abriss, ed. K. Cieślak, introductory and commentary in Germ. C. Badstübner-Kizik with coop. K. Cieślak, H. Nogossek, Gdańsk 1999, pp. 220-221.

13 M.G. Müller, Zweite Reformation und städtische Autonomie im Königlichen Preussen. Danzig, Elbing und Thorn in der Epoche der Konfessionalisierung (1557-1660), Berlin, 1997, pp. 111-137. P.P. Bajer, op. cit., p. 240, erroneously wrote that the church of St. Elisabeth became Calvinist as early as 1547 . This is impossible, however, since at that time in Gdansk no one had yet heard of Calvinism. The Second Calvinist Reformation began in Gdańsk in 1586 .
} 
Bosgrave had demonstrated insubordination to his supervisor, Possevino did not take him to Stockholm. ${ }^{14}$ Another Jesuit was Robert Abercromby. He was of Scottish origin and an adviser to Hieronim Rozrażewski, the bishop of Włocławek, in matters related to Gdansk, including the location of a Jesuit college there. ${ }^{15}$ Also, Patrick Gordon of Auchleuchries, a Scot and a Catholic emigrant, was a nobleman who must have visited Gdansk, as later he was a student of the Jesuit college in Braniewo. ${ }^{16}$ However, there were no British nationals among over 900 Jesuits who worked in the Jesuit Society centre in Gdansk since its foundation in 1585 to the dissolution of the order in $1773 .{ }^{17}$ Among ordinary Gdansk Catholics the supposed English and Scots were rather rare. Within the group of Gdansk Catholics between 1608-1640, which was rather thoroughly investigated by the author, very few, among the approximately 2,550 identified surnames, could belong to people of English origin (such as Jacob Byrd, Thomas Carr, Martinus Hull, Elisabeth Law, Regina Law and Thomas Law). ${ }^{18}$ However, in the Stare Szkoty suburbs belonging to Catholic bishops, seven British sounding surnames can be found in the register of residents containing 209 persons in total (the heads of families) dated 1597. Five of them - as recorded in the list - were Calvinists (Albinus Pikock, Sibertus Tomson, Nicolaus Rompell, Hermanus Potter and Franciscus Potter), one was a Lutheran (Petrus Hill), and one a Mennonite (Georgius Reddick). There was no surname of this kind among 96 Catholics. ${ }^{19}$

\section{Calvinists (Presbyterians) and Anglicans from the British Isles in Gdansk before the foundation of the British Chapel (the so-called English Church) in 1707}

The newcomers from England and Scotland, who arrived in Gdansk at the turn of the $16^{\text {th }}$ and $17^{\text {th }}$ century, could be Anglicans (or Puritans) from England, but Scottish Presbyterians undoubtedly continued to be more active in settling in Gdansk. According to Theodor Fischer, Scottish surnames appeared in the parish registers of the churches of St. Peter and Paul and of St. Elisabeth (not associated with Calvinism at all at the time) ever since the registers have been kept in these churches, which is from around $1573 .{ }^{20}$ This issue was investigated in detail by Peter Paul Bajer, who demonstrated a steady increase in the number of Scottish surnames recorded at St. Peter and Paul's from 1590, which was in the period during which the church was really in the hands of Gdansk Reformed Evangelicals. This growth continued until the middle of the $17^{\text {th }}$ century (131 baptisms in the 1740's and 126 in the 1750's) and then slowed down to approximately 50-60 baptisms (over a decade) at the turn of the $17^{\text {th }}$ and $18^{\text {th }}$ century. ${ }^{21}$ The same growth tendency was also observed in the other Calvinist centre in Gdansk, namely St. Elisabeth's church. In the 1740's, a total of 242 baptisms and 78

\footnotetext{
14 S. Kościelak, Jezuici w Gdańsku od drugiej połowy XVI do końca XVIII wieku, Gdańsk-Kraków 2003, p. 26.

15 Ibidem, p. 27.

16 P.P. Bajer, op. cit., p. 135.

17 See S. Kościelak, Skład osobowy Kolegium Gdańskiego OO. Jezuitów w Gdańsku (XVI-XVIII w.), Gdańsk 2005.

18 Idem, Rejestr katolików gdańskich pierwszej połowy XVII wieku. Problem przydatności i wiarygodności ksiag metrykalnych $w$ badaniach nad stosunkami wyznaniowymi $w$ dużym protestanckim ośrodku, "Textus et Studia", 4/2015, pp. 25-46.

19 Archiwum Diecezjalne we Włocławku [The Diocesan Archives in Włocławek], ABKP, 12 (32), Akta biskupa Rozrażewskiego [The Files of Bishop Rozrażewski], f. 243-245.

20 T.A. Fischer, op. cit., p. 145.

21 P.P. Bajer, op. cit., p. 237.
} 
marriages among persons of Scottish origin were recorded in these two parishes. ${ }^{22}$ Obviously, not all of these people can be considered permanent residents in Gdansk. According to the data provided by the English residents, only 21 Scotsmen and Englishmen (heads of the families) ${ }^{23}$ resided in Gdansk in 1650 . This, in turn, could be a considerably underestimated number. Scotsmen/Presbyterians would apply for the city's citizenship, and tried to do so, particularly after 1577 . They had surnames which occurred repeatedly (e.g. Murray) in Gdansk parish registers and also for many later generations. Some of them such as Thomas Gregor, Thomas Griffin and Jacob Brown, ${ }^{24}$ when applying for the citizenship referred to the services they rendered during the war with Stephen Báthory. Based on the extracts from the parish registers of both Calvinist churches in Gdansk, the representatives of the Aidys, Buchans, Clarks, Davidsons, Forbes, Gourlays, Stuarts and Turners (St. Peter and Paul's) and of the Andersons, Hamiltons, Morrisons, Ramseys and Thomsons (St. Elisabeth's) ${ }^{25}$ could be counted among the distinguishing residents/citizens of Scottish/ Presbyterian origin in the $17^{\text {th }}$ century. Among the many merchants of Scottish origin, who were active in both these religious communities and involved in charitable works, Daniel Davidson (another spelling of his surname being Davisson) deserves a special mention. He was born in 1647 in Zamość in the south of Poland (his father coming from Edinburgh), but later he became a very rich and influential citizen of Gdansk. He was, among other things, the manager of the Smallpox Patients' Hospital (German: Pockenhaus) and an elder in the St. Peter and Paul's Calvinist community. On his deathbed, he established a foundation and several legacies for poor Calvinist students from Poland and for widows and orphans from Gdansk. The foundation continued to work in the $18^{\text {th }}$ century. ${ }^{26}$

Such a large Scottish/Presbyterian (or, in broader terms, British) community needed appropriately trained ministers and showed a tendency to retain a certain autonomy in this regard. Allegedly, in around 1588, there was a Scottish reformed community in Gdansk. ${ }^{27}$ The location of its church/chapel, however, is unknown. Dedicated clergymen of this denomination and nationality also appeared in Gdansk in the middle of the $17^{\text {th }}$ century. In 1639 , it was William Guild of Aberdeen, Scotland. Several decades later (during the reign in England and Scotland of Charles II Stuart), Jacob Brown came to Gdansk. He was responsible for running a Scottish religious community in Koenigsberg, the capital city of Electoral Prussia, upon an order from the Great Kurfirst (Electoral Prince) Frederick William, Elector of Brandenburg

\footnotetext{
22 Ibidem, p. 242.

23 Ibidem, p. 243.

24 Fischer counted approximately a hundred Scottish surnames in these two churches between 1573 and 1699 . He found them less frequently in other churches in Gdansk, which were, in a later period, more closely associated with Lutheranism. Almut Hillebrand, in turn, showed that between 1700 and 175566 children from families of Scottish origin were baptized at St. Peter and Paul's. See: T.A. Fischer, op. cit., pp. 43-44, 145, 193-198, 221-232. A. Hillebrand, op. cit., p. 207.

25 P.P. Bajer, op. cit., pp. 245, 391-419.

${ }_{26}$ T.A. Fischer, op. cit., p. 63. M. Dunsby, op. cit., p. 9. According to her, the task of the foundation was to teach young Scots at theological schools in Edinburgh and Leiden so that they could later become preachers in the Reformed Evangelical communities in Poland. As for the Davidsons, see also A. Biegańska, Andrew Davidson (1591-1660) and his descendants, "Scottish Slavonic Review", 10/1998, pp. 7-18.

27 M. Dunsby, op. cit., p. 2.
} 
(who himself also professed Calvinism). ${ }^{28}$ Another preacher from the British Isles, Samuel Hammond, travelled between Gdansk, Koenigsberg and Elbląg at this time. There is, however, no concrete information about his denomination (or nationality). ${ }^{29}$

In 1640, Francis Gordon of Braco, an English resident in Gdansk, negotiated with the City's Council the possibility of obtaining a bigger space (capacior locus) for the needs of religious services for the subjects of the king of England (and Scotland). The suggested locations included the Green Gate and the surroundings of the city's Shooting Range in the Nowe Ogrody suburbs. ${ }^{30}$. We know that he had to be a Presbyterian because, having married Anna Wegner, a citizen of Gdansk, he baptized all his five children at St. Peter and Paul's. ${ }^{31}$ We know that the places indicated for ministry were not obtained. In the same year, however, the English merchants rented some rooms in the town house at 16 Szeroka Street for their professional needs. This house was later popularly called the English House. The merchants kept the place until 1690 and also frequently used it as a venue for prayer meetings and religious services. ${ }^{32}$ We may only suppose that these services were more Presbyterian (Puritan) than Anglican, but we do not know the names of the clergymen at that time except those mentioned above, together with Robert Moiler who is listed by Ephraim Praetorius under the year 1652. ${ }^{33}$ From 1692 (1693) to 1712, one of the preachers in Gdansk was Thomas Burnet (Bournett), who celebrated services in his private flat on Mariacka Street, in the heart of the Main Town. Also, his house in the Żwirownia (Sandgrube) suburbs was used as a venue for meetings. ${ }^{34}$ Like Guild, he was of Scottish origin and came from Aberdeen, but worked in Edinburgh for some time..$^{35}$ Also Scottish was Alexander Becks, another clergyman using his private house at Za Murami Street (Hintergasse) in his work for his fellow countrymen. ${ }^{36}$

\section{The British Chapel (English Church) in Gdansk in the $18^{\text {th }}$ Century, the chapel's furnishings and the nature of pastoral work}

Closer economic relations between Gdansk and England at the beginning of the $18^{\text {th }}$ century resulted in the signing in 1706 of a trade agreement. One of the signatories was an English resident in Sweden, John Robinson, who also represented the interests of his country in the southern Baltic Sea area. In addition to the points concerning the exchange of commodities, the agreement also contained a clause on the provision for the religious needs of the British

\footnotetext{
28 Ephraim Praetorius calls him Broen and dates his activity at an unspecified time before 1652. Dunsby, in turn, while referring to the documents that no longer exist of the English Church in Gdansk, presents an opinion dating back to ca. 1664 stating that he supposedly preached radical, somewhat Quaker ideas. Fischer puts him at the Kurfirst's court in around 1685. See: E. Praetorius, Danziger Lehrer Gedachtnis, Dantzig u. Leiptzig 1760 , p. 73. T.A. Fischer, op. cit., p. 140; M. Dunsby, op. cit., p. 2.

29 Ibidem, p. 3.

30 Ibidem, p. 2. A, Hillebrandt, op. cit., p. 97.

31 P.P. Bajer, op. cit., p. 168. Francis Gordon was also a representative of the Kingdom of Denmark in Gdansk. In 1643 he came back to Scotland, Aberdeen, and died there. See: Dzieje przedstawicielstw Królestwa Danii w Gdańsku, eds. A. Kłonczyński, P. Paluchowski, Pelplin 2019, pp. 66-67.

32 Ibidem. More in: E. Barylewska-Szymańska, Dom Angielski, in: Encyklopedia Gdańska, ed. B. Śliwiński, Gdańsk 2012, p. 231.

33 E. Praetorius, op. cit., p. 73.

34 M. Dunsby, op. cit., p. 2.

35 Ibidem, p. 7.

36 Ibidem, p. 2.
} 
people coming to Gdansk. A preacher, exempt from city taxes (excise), was to be appointed for them, but it was envisaged that he would celebrate services in a private house. ${ }^{37}$ Article 9 of the agreement clearly stipulated that this was to be an Anglican clergyman. ${ }^{38}$ A propitious atmosphere in mutual relations immediately after the signing of the agreement, and the proclamation of the real union between England and Scotland in May 1707, prompted the British people living by the Motława river to keep up the momentum and found, upon consent from the city authorities, a separate "British chapel" (The Great Brittans Chapell). Later, the chapel was also referred to in documents as the English Church (German: Englische Kirche). Around three hundred merchants contributed money towards the foundation, but the largest sums were given by Scots Thomas Leslie and Samuel Ramsey. ${ }^{39}$ Both of these men were often mentioned in the parish register of the Calvinist community of St. Peter and Paul's church in the Old Suburbs. ${ }^{40}$ The town house purchased was located in the Main Town, at 80 , Św. Ducha Street, which was the former house of the Skippers' Guild. ${ }^{41}$ According to an entry in the Main Town's land register, the city authorities recognised the building's special character i.e. its usage for worship and services for British merchants. ${ }^{42}$

The furnishings in the chapel were remarkably unsophisticated and conducive to the denominational syncretism. There was an organ and pulpit there, and for an altar a table which had been carved and gilded, was used. The chapel walls were decorated with the British coats of arms (English and Scottish) and two large paintings depicting Moses carrying the tablets with the Ten Commandments and the texts of the Confession of Faith and Lord's Prayer against a background of the rising sun. ${ }^{43}$ Such ornaments certainly did not disturb the religious sensitivity of the Calvinists (should they have used the chapel), but neither would they have upset the faithful Anglicans. ${ }^{44}$ Also, the community's liturgical silverware mentioned in 1812, which was towards the end of the activity of the British religious community, was typical for the simplest church tasks and was used for baptism (a can and bowl) and the Lord's Supper (a chalice). ${ }^{45}$

The attitude of the clergymen working in Gdansk certainly influenced the character of the denomination and the distinctive calvinisation of the English Church. A rule was introduced specifying that the British clergy working in Gdansk should represent both British nationalities interchangeably: an Englishman ought to follow a Scotsman. However, it does not seem that the rule was adhered to consistently. Most preachers of the English Church in Gdansk came from Scotland. Each time a new clergyman arrived, he was supposed to conform to the customs and rite observed in Gdansk, ${ }^{46}$ which could also lead to a stronger Calvinist influence. The first user of the new chapel, the above-mentioned Thomas Burnet, was already

\footnotetext{
37 Ibidem, p. 3.

38 A. Hillebrand, op. cit., p. 116.

39 M. Dunsby, op. cit., p. 3.

40 Archiwum Państwowe w Gdańsku [State Archive in Gdansk, hereafter: APG], 356/6: 3, 289, 297, $304,306$.

41 S. Kościelak, Kalwini w Gdańsku, in: Encyklopedia Gdańska, op. cit., p. 434.

42 APG, 300,32/12: 131.

43 M. Dunsby, op. cit., p. 3.

44 The Anglicans preserved many Catholic relics in their rite, including paintings and ornaments. Calvinists avoided any religious symbols but would probably be inclined to accept the content of the most basic truths of faith.

45 Ibidem, p. 11.

46 Ibidem, p. 4.
} 
made to feel that he was a Calvinist. In 1712, after his death, he was buried with honours in the crypt of the Calvinist church of St. Peter and Paul in the Old Suburb. The funeral speech was delivered by the minister of this church, Stephan Wolters. ${ }^{47}$ Between 1714-1723, the minister was Alexander Davidson. ${ }^{48}$ Even if he officially conducted worship in the Anglican way, which seems to be suggested in a report about Gdansk made while he was the minister, but published in London in 1734, ${ }^{49}$ the fact that he ranked among the Jacobites and did not want to pray for King George made the majority of the congregation in Gdansk turn their backs on him and choose, as it is stated in the source cited, a "Communion with Calvinists." ${ }^{50}$ After Davidson's death, William Bickerton (Bucketon) was brought from England to Gdansk. Perhaps he was a more orthodox Anglican, but no concrete information about his denominational preferences is available. When he left the Polish-Lithuanian Commonwealth in $1727,{ }^{51}$ he was replaced by Peter Hay. He was the preacher at the British Chapel between 1727-176052. He was also the first married British clergyman in Gdansk, and was married at the Calvinist church of St. Elisabeth in the Old Town. ${ }^{53}$

After a very short service in Gdansk of the next two clergymen: John Tucker (ca. 1762) and Joshua Kenworthy (1763), Richard Jameson came to the office in October 1764. He was yet another Scotsman and a doctor of theology from Edinburgh, ${ }^{54}$ the teacher and educator of Johanna Schopenhauer, (the author of Jugendleben und Wanderbilder and a Lutheran by the way) who always spoke about him in a warm and respectful way. ${ }^{55}$ In Almut Hillebrand's opinion, Jameson was an Anglican clergyman. ${ }^{56}$ However, the Gdansk personal directories, published since 1743 and printed every year under the common name of Das jetzt-lebende Danzig, clearly and unambiguously ranked him and his predecessors among reformed preachers (as was the case with each minister from the local French Huguenot community).$^{57}$ After the end of his mission in Gdansk, he went back to his homeland in 1789 and died in Newcastle, north-east England. From 1790, his successor was William Gardiner, who also held the title of Doctor of Theology. During his ministry, the English Church continued to be in close contact and cooperation with the Calvinist church of St. Peter and Paul, as evidenced

47 Ibidem, p. 7.

48 Patrizier, Bürger, Einwohner der Freien und Hansestadt Danzig in Stamm- und Namentafeln vom 14-18 Jahrhundert, ed. D. Weichbrodt, Klausdorf-Schwentine 1986, vol. 1, p. 129, did not manage to relate him to the core of that family of rich merchants from Edinburgh and later from Zamość. The line of Alexander, a clergyman, came from Aberdeen, Scotland. See also P.P. Bajer, op. cit., p. 297.

49 A Particular Description of the City of Dantzick... by an English Merchant, lately Resident there, London 1734.

50 Ibidem, p. 41.

51 E. Praetorius, op. cit., p. 73. M. Dunsby, op. cit., p. 7.

52 E. Praetorius, op. cit., p. 73.

53 M. Dunsby, op. cit., pp. 7-8.

54 Ibidem, p. 8.

55 J. Schopenhauer, Gdańskie wspomnienia młodości, transl. T. Kruszyński, Gdańsk 2010, pp. 42-44.

56 A. Hillebrand, op. cit., p. 201.

57 The recently published printed version of Das jetzt-lebende Danzig. Anno 1777, in: Das Danziger Adressbuchwasen, ed. von R. Wenzel, mit den Nachdrucken: Das jetzt-lebende Danzig. Anno 1777; Adressbuch des Koenigl. Westpreussischen See - und Handelsstadt Danzig und der combinierten Städte Stolzenberg für Jahr 1797, Adressbuch des Landeskreises Danzig 1888, „Sonderschriften des Vereins für Familienforschung Ost - und Westpreussen e.V.“, No. 89, Hamburg 2004, p. 33. For other $18^{\text {th }}$ century personal registers see Polska Akademia Nauk Biblioteka Gdańska [the Polish Academy of Sciences, the Gdansk Library], Uph. o. 4847 and Uph. o. 4848. 
by joint charity campaigns conducted for the Gdansk orphanage. ${ }^{58}$ The British community in Gdansk also provided several ministers (preachers) who supported pastoral work in the traditional Calvinist churches in the city. At St. Peter and Paul's (and St. Elisabeth's), these were Jacob Buchan (1718-1776) and his son, Peter Jacob Buchan (1753-1814), Franz Bellair (1762-1831), and an outstanding Enlightenment activist and a promoter of English culture by the Motława river, Samuel Wilhelm Turner (1739-1806). ${ }^{59}$

\section{The British community centred around the English Church and Calvinist parishes}

After the foundation of the British Chapel, most of the members of the British community in Gdansk still came from Scotland and gave the entire colony its Scottish and Presbyterian character. ${ }^{60}$ The real management of the chapel and its assets was actually the responsibility of three to five church finance administrators. In addition to these administrators, five to six managers of the British Poor Fund (also called the deacons or elders of the English Church) were appointed. Among the elders, the names of the most respectable British citizens of Gdansk, such as Ramsey, Leslie, Gibsone, Kabrun and Maclean, are mentioned. They were both Scots and Calvinists at the same time. Examples include Archibald Gibsone who, due to his Scottish origin, was initially accused of supporting the Stuarts, who had been removed from the English throne. For this reason, he was looked upon with distrust by the government in London, which was faithful to the House of Hanover. Eventually, however, he was appointed a deputy resident in 1724-1735, and the British resident (consul) in Gdansk from 1735 to 1750 . He baptised his children in the Calvinist church of St. Peter and Paul, which attracted the wealthier part of the Reformed Evangelical community in Gdansk. Towards the end of his life, between 1761 and 1779, he was one of the administrators of the English Church. ${ }^{61}$ Also, Scottish and well-rooted in the Calvinist community of Gdansk were the families of the Clercks, Davidsons and Macleans (the last ones being strongly associated with the francophone Calvinist community, the descendants of the French Huguenots) ${ }^{62}$ At the turn of the $18^{\text {th }}$ and $19^{\text {th }}$ century, a family of ship owners of Scottish background, the Kabruns, became very important in Gdansk. The members of this family would frequently attend the sacramental services in the Calvinist Churches of St. Peter and Paul, and of St. Elisabeth. ${ }^{63}$ Some of these wealthy Scots/Presbyterians involved in the life of the British community would also become members of lay bodies managing the general city's Reformed Evangelical structure. In the $18^{\text {th }}$ century, among the members of an advisory and inspec-

\footnotetext{
58 M. Dunsby, op. cit., p. 10.

59 L. Rhesa, Kurzgefasste Nachrichten von allen seit der Reformation an den evangelischen Kirchen in Westpreussen angestellten Predigern, Königsberg 1834, pp. 80-81. T.A. Fischer, op. cit., p. 137, mentions the younger of the Buchans, but he twists the surname Turner to Thomson in a certain place. Obviously, according to him both of them were Scottish. More about Turner and his importance: A. Hillebrand, op. cit., pp. 239-307. See also P.P. Bajer, op. cit., pp. 296-297.

60 Ibidem, p. 212.

${ }^{61}$ Ibidem, p. 206. Hillebrand referred to a periodical from the Gdansk Library of the Polish Academy of Sciences (PAN) - "Wochentliche Danziger Anzeigen", but their surnames are also mentioned by the Gdansk directory of 1777. There were Adam Elliot and Michael Barstow among church managers, too. In addition to the two persons mentioned before, the British Poor Fund was also managed by John Atkinson, Wilhelm Theodor Houwens and Henry Simson. See Das Danziger Adressbuchwasen, p. 30.
}

62 A. Hillebrand, op. cit., pp. 210-221, 312.

63 Ibidem, p. 312. 
tion body, the so-called College of the Thirteen (Collegium der Dreyzehner) were Wilhelm Turner, George and Wilhelm Moir, and Johann Daniel Clerck. ${ }^{64}$ This is, therefore, excellent evidence of the assimilation of various ethnic groups of the city's Calvinist community. Indeed, there must have been very few who actually used the British Chapel. According to the calculations made by Almut Hillebrand which is based on statistical data from a periodical titled the Wochentliche Danziger Anzeigen, within 22 years investigated by her from the period between 1749 and 1791, baptisms in the English Church were administered only 31 times (thus approximately 1.5 times a year), 11 marriages were solemnised ( 0.5 per year) and 1 burial ceremony was conducted. ${ }^{65}$ Thus, this would be a community of only a few (around a dozen) families, which would identify their nationality (British) more strongly than their denomination. Obviously, given the current state of the surviving sources, it cannot be excluded that it was precisely these who underlined the distinction of their denomination (as Anglicans or perhaps, even more strongly, English Puritans), whilst at the same time willingly commission the management of their church to the wealthy Scottish Presbyterians.

A characteristic feature of the majority of these Scottish Calvinists was their tendency to melt into the local community of the citizens of Gdansk. The marriages between the persons of Scottish (Calvinist) origin with the representatives of the most important Gdansk patrician families, not always associated with Calvinism, were spectacular. These developments took place as early as the $17^{\text {th }}$ century, and one of the most remarkable examples is the case of a Scot, Thomas Gellatlay. By affiliating himself through marriage in 1623 with the Zierenbergs (Czirenbergs), the leaders of the Calvinist wing in Gdansk, he started - after the surname became Germanised - the family of the Gellentins, who soon gained access to power in the city on the Motława river. More frequently, however, these marriages were concluded with the Lutherans (e.g. William Patterson, a Scottish colonel serving the city, who married a daughter of the mayor, Adrian von der Linde, in 1664, or the granddaughter of above-mentioned Daniel Davisson, Charlotta Constantia Beata, who in 1783 married a mayor and scientist, Carl Friedrich von Gralath). ${ }^{66}$ The Uphagens were an interesting example of those commencing relations with the English colony through marriage. They were, admittedly, of Dutch origin, but when Peter Uphagen, a rich merchant and ship owner, married Miss Elizabeth Forret of Scottish origin (the wedding ceremony took place at St. Peter and Paul's), he himself started providing for the English Church in Gdansk and for the clergy of that church ${ }^{67}$. However, the prosperity of the British (Scottish) community in Gdansk ended with the Napoleonic era and the French occupation of the city since 1807.

\footnotetext{
${ }^{64}$ Wider in this issue see: S. Kościelak, Srodowisko gdańskich kalwinistów w połowie XVIII wieku, in: Dysydenci czy decydenci? Protestanci w obu częściach Prus i Koronie w XVI-XVIII wieku, ed. W. Zawadzki, Elbląg 2018, pp. 129-154.

${ }_{65}$ A. Hillebrand, op. cit., p. 206. This last thing should not be surprising. The British did not have a cemetery of their own, so they used other parish burial grounds, probably Calvinist ones.

66 T.A. Fischer, op. cit., pp. 112-113.

67 M. Dunsby, op. cit., p. 7.
} 


\section{British radicals: Chiliasts and Quakers in Gdansk ${ }^{68}$}

Besides the above-mentioned religion(s) other British religious - especially more radical groups lived or try to live in Gdansk in $16-18^{\text {th }}$ centuries. Chiliasts, who preached that the end of the world was near and were expelled from England by Elisabeth I, arrived in Gdansk in 1600. They were led by Thomas Leamer, a preacher, prophet and an English merchant from Amsterdam. Eventually, the public dispute between Arians and Chiliasts was dispelled by city lackeys, and Leamer was accused of bigamy and imprisoned. ${ }^{69}$ Later, he was active in the Netherlands and tried to join a group of the local Anabaptists, but was, in turn, suspected of Arian chiliasm. ${ }^{70}$

In the second half of the $17^{\text {th }}$ century in the neighbourhood of Gdansk there appeared the Quakers i.e. those who "quake", named this way after their mystic way of experiencing contact with God. They left England after 1660 as a result of the restoration of the House of Stuarts there. ${ }^{11}$ Stricter anti-Quaker legislation in Gdansk was enacted, particularly in 1677-1678 , when disputes of a social nature swept through the city. The aversion of a religious character to a group which was completely different from the point of view of the principles of faith coincided with a reluctance of an economic nature against that group because of its manifested thrift and diligence, which was dangerous within the sphere of economic competition. ${ }^{72}$ Therefore, a joint Lutheran and Catholic commission was created which, in January 1678 , became involved in the assessment of the views held by the religious radicals of various groups inhabiting the city. The presence and activity of the Quakers, often called the enthusiasts ("Enthusiasten"), received widespread condemnation. ${ }^{73}$ A decree against the Arians and Quakers was issued on 12th February 1678 by John III Sobieski who was staying in Gdansk at the time. ${ }^{74}$ The Quakers, as the "peace-loving neighbours and brothers in Christian faith", were defended at that time in front of the Gdansk authorities, which also jointly managed the settlement/suburbs called Siedlce (where the greatest number of the radicals/Quakers lived), by a William Gibson. He is perhaps an ancestor of the previously mentioned Alexander Gibsone and Archibald Gibsone. ${ }^{75}$ Therefore, despite the various methods of combating this radical denominational group through, among other things, the publication of written polemics, ${ }^{76}$ the Quakers in Gdansk managed to organise themselves at a basic level and convene secret autonomous synods for several years in a row from 1682,

\footnotetext{
68 More about this issue also in: S. Kościelak, Gdańsk XVI-XVIII wieku - bezpieczna przystań dla religijnych uchodźców? Z dziejów koegzystencji międzywyznaniowej w epoce nowożytnej, "Studia Historica Gedanensia", 5/2014, pp. 203, 205-206.

69 J. Tazbir, Antytrynitaryzm w Gdańsku i okolicach, „Odrodzenie i Reformacja w Polsce”, 21/1976, p. 63.

70 K.L. Sprunger, Dutch Puritanism: A History of English and Scottish Churches of the Netherlands in the Sixteenth and Seventeenth Centuries, Leiden 1983, "Studies in the History of Christian Thought", No. 31 , p. 82.

71 M. Wajsblum, Quakers and Poland, 1661-1919, “The Polish Review”, 11/1966, No. 2, pp. 12-13.

72 Ibidem, p. 13.

73 S. Kościelak, Katolicy w protestanckim Gdańsku, op. cit., p. 170.

74 E. Cieślak, Obraz społeczeństwa gdańskiego i jego życia codziennego, in: Historia Gdańska, ed. E. Cieślak, vol. 3/1, Gdansk 1993, p. 255.

75 W. Gibson, Christliche Ansprache an die Obrigkeit in Dantzig und Schiedlitz wegen etlicher alldar verfolgten Christen, Amsterdam 1679. See also A. Biegańska, The Learned Scots in Poland (From the Mid-Sixteenth to the Close of the Eighteenth Century, "Canadian Slavonic Review", 43/2001, No. 1, p. 7.

76 S. Kościelak, Scrutator Veritatis. Drukowane dysputy teologiczne w Gdańsku w drugiej połowie XVII wieku, "Zapiski Historyczne”, 68/2003, vol. 2-3, pp. 83-87.
} 
and also separate synods for female Quakers, which was an exception on the European continent. ${ }^{77}$ In 1689 the City Council, however, issued another edict, forbidding the Quakers to rent houses, flats or even rooms for meetings, and ordered the Quakers to vacate the premises already used by them immediately. ${ }^{78}$ The Quakers began to leave the territory of Royal Prussia gradually and move to the British colonies in North America (mainly to Pennsylvania). The last Gdansk Quaker died in $1721 .^{79}$

\section{Bibliography}

\section{Sources}

Das Danziger Adressbuchwasen, von R. Wenzel, mit den Nachdrucken: Das jetzt-lebende Danzig. Anno 1777; Adressbuch des Koenigl. Westpreussischen See - und Handelsstadt Danzig und der combinierten Städte Stolzenberg für Jahr 1797, Adressbuch des Landeskreises Danzig 1888, „Sonderschriften des Vereins für Familienforschung Ost - und Westpreussen e.V.“, No. 89, Hamburg 2004.

Frisch G., Der Sankt Marien Pfarrkirchen in Dantzig inwendige Abriss, ed. K. Cieślak, introductory and commentary in Germ. C. Badstübner-Kizik with coop. K. Cieślak, H. Nogossek, Gdańsk 1999.

Gibson W., Christliche Ansprache an die Obrigkeit in Dantzig und Schiedlitz wegen etlicher alldar verfolgten Christen, Amsterdam 1679.

A Particular Description of the City of Dantzick... by an English Merchant, lately Resident there, London 1734.

Patrizier, Bürger, Einwohner der Freien und Hansestadt Danzig in Stamm- und Namentafeln vom 14-18 Jahrhundert, ed. D. Weichbrodt, Klausdorf-Schwentine 1986, vol. 1.

Praetorius E., Danziger Lehrer Gedachtnis, Dantzig u. Leiptzig 1760.

Schopenhauer J., Gdańskie wspomnienia młodości [Memories of Youth in Gdansk], transl. T. Kruszyński, Gdańsk 2010.

\section{Works}

Bajer P.P., Scots in the Polish-Lithuanian Commonwealth, $16^{\text {th }}-18^{\text {th }}$ Centuries: The Formation and Disappearence of an Ethnic Group, Leiden-Boston 2012.

Barylewska-Szymańska E., Dom Angielski [English House], in: Encyklopedia Gdańska [The Encyclopedia of Gdansk], ed. B. Śliwiński, Gdańsk 2012, p. 231.

Biegańska A., Andrew Davidson (1591-1660) and his descendants, "Scottish Slavonic Review", 10/1998, pp. 7-18.

Biegańska A., The Learned Scots in Poland (From the Mid-Sixteenth to the Close of the Eighteenth Century), "Canadian Slavonic Review", 43/2001, No. 1, pp. 3-12.

Cieślak E., Obraz społeczeństwa gdańskiego i jego życia codziennego [The Image of Gdansk's Society and its Everyday Life], in: Historia Gdańska, ed. E. Cieślak, vol. 3/1, Gdansk 1993, pp. 246-278.

\footnotetext{
77 M. Wajsblum, op. cit., p. 13.

78 E. Cieślak, op. cit., p. 255.

79 M. Wajsblum, op. cit., p. 14.
} 
Dunsby M., Die Englische Kirche in Danzig, ,Mitteilungen des Westpreussischen Geschichtsvereins", 31/1932, No. 1, pp. 1-12.

Dzieje przedstawicielstw Królestwa Danii w Gdańsku i Gdyni [The history of diplomatic agencies of the Kingdom of Denmark in Gdansk and Gdynia], eds. A. Kłonczyński, P. Paluchowski, Pelplin 2019.

Fischer T.A., The Scots in Eastern and Western Prussia, Edinburgh 1903.

Hillebrand A., Danzig und die Kaufmannschaft grossbritannischer Nation. Rahmenbedingungen, Formen und Medien eines englischen Kulturtransfers im Ostseeraum des 18. Jahrhunderts, Frankfurt am Main 2009.

Kościelak S., Scrutator Veritatis. Drukowane dysputy teologiczne w Gdańsku w drugiej potowie XVII wieku [Scrutator Veritatis, Printed Theologian Disputes in Gdansk in Second Half of $17^{\text {th }} C$.], ,Zapiski Historyczne”, 68/2003, vol. 2-3, pp. 75-96.

Kościelak S., Jezuici w Gdańsku od drugiej połowy XVI do końca XVIII wieku [Jesuits in Gdansk from the Second Half of the $16^{\text {th }}$ Century to the End of $18^{\text {th }}$ Century], Gdańsk-Kraków 2003.

Kościelak S., Katolicy w protestanckim Gdańsku od drugiej połowy XVI do końca XVIII wieku [Catholics in Protestant Gdansk from the Second Half of the $16^{\text {th }}$ to the End of the $18^{\text {th }} C$.], Gdańsk 2012.

Kościelak S., Kalwini w Gdańsku [Calvinists in Gdansk], in: Encyklopedia Gdańska [The Encyclopedia of Gdansk], ed. B. Śliwiński, Gdańsk 2012, p. 434.

Kościelak S., Gdańsk XVI-XVIII wieku - bezpieczna przystań dla religijnych uchodźców? $Z$ dziejów koegzystencji międzywyznaniowej w epoce nowożytnej [Sixteenth to Eighteenth Century Gdańsk - a Safe Haven for Religious Refugees? On the History of Religious Coexistence in the Modern Era], "Studia Historica Gedanensia", 5/2014, pp. 196-215.

Kościelak S., Rejestr katolików gdańskich pierwszej połowy XVII wieku. Problem przydatności i wiarygodności ksiag metrykalnych w badaniach nad stosunkami wyznaniowymi $w$ dużym protestanckim ośrodku [Register of Gdansk Catholics in the First Half of the $17^{\mathrm{h}}$ Century. The Problem of the Usefulness and Credibility of Parish Registers in a Research on Relations between Denominations inside a Large Protestant Centre], "Textus et Studia". 4/ 2015, pp. 25-46.

Kościelak S., Środowisko gdańskich kalwinistów w połowie XVIII wieku [The community of the Calvinists of Gdansk in the mid-18th century], in: Dysydenci czy decydenci? Protestanci $w$ obu czesściach Prus i Koronie w XVI-XVIII wieku [Dissidents or decission makers? Protestants in both parts of Prussia and the Crown of Poland in 16-18 $8^{\text {th }}$ centuries], ed. W. Zawadzki, Elbląg 2018, pp. 129-154.

Müller M.G., Zweite Reformation und städtische Autonomie im Königlichen Preussen. Danzig, Elbing und Thorn in der Epoche der Konfessionalisierung (1557-1660), Berlin 1997.

Rhesa L., Kurzgefasste Nachrichten von allen seit der Reformation an den evangelischen Kirchen in Westpreussen angestellten Predigern, Königsberg 1834.

Sprunger K.L., Dutch Puritanism: A History of English and Scottish Churches of the Netherlands in the Sixteenth and Seventeenth Centuries, Leiden 1983, "Studies in the History of Christian Thought", No. 31.

Tazbir J., Antytrynitaryzm w Gdańsku i okolicach [Anti-trinitarianism in Gdansk and its Neighbourhood], „Odrodzenie i Reformacja w Polsce”, 21/1976, pp. 57-82.

Wajsblum M., Quakers and Poland, 1661-1919, “The Polish Review”, 11/1966, No. 2, p. 11-22. 